\title{
Computing Capital Budgeting for Banking Sector
}

\author{
Sushain Koul ${ }^{1}$, Dr. Parag Ravikant Kaveri \\ ${ }^{1}$ Student, Symbiosis Institute of Computer Studies and Research, Pune, 411016, India \\ ${ }^{2}$ Department of Computer, Symbiosis Institute of Computer Studies and Research, Pune, 411016, India \\ 1'suk1941073@sicsr.ac.in, 2parag.kaveri@sicsr.ac.in
}

\begin{abstract}
Perhaps the most difficult hurdle which companies come across is the selection of the project which is beneficial to the organization in the longrun and also increases the present value of the shareholders. This is where Capital Budgeting comes into play. Capital Budgeting is one of the most important areas of financial management. This paper gives an overview of what capital budgeting is, what different types of techniques comes under capital budgeting and how to represent capital budgeting technique algorithmically. In this paper we also throw some light on what the results of various capital budgeting techniques will be if any banking organization follows these techniques and compare those results. These techniques namely as Payback Period (PP), Average Rate of Return (ARR), Net Present Value (NPV), Profitability Index (PI) and Internal Rate of Return (IRR) are used to evaluate projects.
\end{abstract}

Index Terms

Capital Budgeting, Cash Flow, Discount Rate, Time Value of Money

Article Received: 10 August 2020, Revised: 25 October 2020, Accepted: 18 November 2020

\section{Introduction}

An organizaton's success or failure depends on capital budgeting decisions. Capital budgeting decisions among several costly long-term investments play a profound impact on the organization and long-term performance. A capital budgeting decision can be stated as the process that companies use for making decisions on long-term projects. Such type of decisions are generally taken in line with the goal of maximizing shareholders value. A firm's investment decisions would generally include expansion, acquisition, modernisation and replacement of long-term assets. The decisions to invest in fixed assets are made by the managers as these are one of the major judgements. Capital budgeting involves various techniques which give a clear picture about which project is profitable. When a project is finalized, initial investment is made and then it is expected that future cash flows are calculated and discounted to the present value. If all the expected future discounted cash flows when combined together is greater than initial investment the project is said to be profitable.

\section{Objective}

To understand the practical use of capital budgeting methods in a banking organization for decision- making.

To learn the significance of capital budgeting in valuing the project for financing.

\section{Methodology}

The information of this research paper has been compiled through Primary and Secondary Sources.

\section{Algorithm}

\section{A. Payback Period}

Step1: Start

Step2: Read initial_inv (initial investment) value from the user

Step3: Set pbdt (profit before depreciation and tax), pbt (profit before tax), np (net profit), ci (cash inflow) as the empty list

Step4: Set sum1 and c variable as zero

Step5: Read sal_value (salvage value), 1 (expected life) and tax from the user

Step6: For i=0 to 1 Do

Step7: Read Profit Before Depreciation and Tax for each year

from the user and append it in pbdt list

Step8: End For

Step9: Compute Depreciation= $($ initial_inv-sal_value $) / 1$

Step10: For i=0 to 1 Do

Step11: Compute pbdt[i]-Depreciation and append each value in pbt list

Step12: End For

Step13: For $i=0$ to 1 Do

Step14: Compute pbt[i]-(pbt[i]*(tax/100)) and append each value in $\mathrm{np}$ list

Step15: End For

Step 16: For $\mathrm{i}=0$ to 1 Do

Step17: Compute np[i]+Depreciation and append each value in ci list

Step18: End For

Step19: For $\mathrm{i}=0$ to 1 Do

Step20: Compute sum1=sum $1+\mathrm{ci}[\mathrm{i}]$

Step21: Check If sum1 is less than initial_inv

Step22: If True, Compute $c=c+1$

Step23: If False, Compute $\mathrm{pb}=\mathrm{c}+(($ initial_inv-(sum1$\mathrm{ci}[\mathrm{i}])) / \mathrm{ci}[\mathrm{i}])$ and break out of the loop

Step25: Print pb 
Step26: Stop

\section{B. Average Rate of Return}

Step1: Start

Step2: Read initial_inv (initial investment) value from the user

Step3: Set pbdt (profit before depreciation and tax), pbt (profit before tax), np (net profit), ci (cash inflow) as the empty list

Step4: Set sum1, avp and avi variable as zero

Step5: Read sal_value (salvage value), 1 (expected life) and tax from the user

Step6: For $\mathrm{i}=0$ to $1 \mathrm{Do}$

Step7: Read Profit Before Depreciation and Tax for each year from the user and append it in pbdt list

Step8: End For

Step9: Compute Depreciation= $($ initial_inv-sal_value $) / 1$

Step10: For i=0 to 1 Do

Step11: Compute pbdt[i]-Depreciation and append each value in pbt list

Step12: End For

Step13: For $\mathrm{i}=0$ to $1 \mathrm{Do}$

Step14: Compute pbt[i]-(pbt[i]*(tax/100)) and append each value in $\mathrm{np}$ list

Step15: End For

Step 16: For $\mathrm{i}=0$ to $1 \mathrm{Do}$

Step17: Compute sum1=sum $1+\mathrm{np}[\mathrm{i}]$

Step18: End For

Step19: Compute avp=sum1/1

Step20: Compute avi= (initial_inv+sal_value) $/ 2$

Step21: Compute arr $=(\text { avp/avi })^{*} 100$

Step22: Print arr

Step23: Stop

\section{Discounted Payback Period}

Step1: Start

Step2: Import math Library

Step3: Read initial_inv (initial investment) value from the user

Step4: Read pbdt (profit before depreciation and tax), pbt (profit before tax), pvf (present value factor), pv (present value), np (net profit) and ci (cash inflow) as the empty list Step5: Set sum1, dpb and c variable as zero

Step6: Read sal_value (salvage value), 1 (expected life), dr (discount rate) and tax from the user

Step7: Compute $\mathrm{dr}=\mathrm{dr} / 100$

Step8: For $\mathrm{i}=0$ to 1 Do

Step9: Read Profit Before Depreciation and Tax for each year from the user and append it in pbdt list

Step10: End For

Step11: Compute Depreciation= $($ initial_inv-sal_value $) / 1$

Step12: For $\mathrm{i}=0$ to 1 Do

Step13: Compute pbdt[i]-Depreciation and append each value in pbt list

Step14: End For

Step15: For $\mathrm{i}=0$ to $1 \mathrm{Do}$

Step16: Compute pbt[i]-(pbt[i]*(tax/100)) and append each value in $\mathrm{np}$ list

Step17: End For

Step 18: For $\mathrm{i}=0$ to $1 \mathrm{Do}$
Step19: Compute np[i]+Depreciation and append each value in ci list

Step20: End For

Step21: For $\mathrm{i}=0$ to $1 \mathrm{Do}$

Step22: Compute $1 /($ math.pow $((1+d r), i+1))$ and append each value in pvf list

Step23: End For

Step24: For $\mathrm{i}=0$ to 1 Do

Step25: Compute ci[i]*pvf[i] and append each value in pv list

Step26: End For

Step27: For $\mathrm{i}=0$ to 1 Do

Step28: Compute sum $1=$ sum $1+$ pv[i]

Step29: Check If sum1 is less than initial_inv

Step30: If True, Compute $\mathrm{c}=\mathrm{c}+1$

Step31: If False, Compute $\mathrm{dpb}=\mathrm{c}+(($ initial_inv-(sum1$\mathrm{pv}[\mathrm{i}])) / \mathrm{pv}[\mathrm{i}])$

Step32: End For

Step33: Print dpb

Step34: Stop

\section{Net Present Value}

Step1: Start

Step2: Import math Library

Step2: Read initial_inv (initial investment) value from the user

Step3: Set pbdt (profit before depreciation and tax), pbt (profit before tax), np (net profit), pv (present value), pvf (present value factor), ci (cash inflow) as the empty list

Step4: Set sum1 variable as zero

Step5: Read sal_value (salvage value), 1 (expected life), dr (discount rate) and tax from the user

Step7: Compute dr=dr/100

Step6: For $\mathrm{i}=0$ to 1 Do

Step7: Read Profit Before Depreciation and Tax for each year from the user and append it in pbdt list

Step8: End For

Step9: Compute Depreciation= $($ initial_inv-sal_value $) / 1$

Step10: For $\mathrm{i}=0$ to 1 Do

Step11: Compute pbdt[i]-Depreciation and append each value in pbt list

Step12: End For

Step13: For $i=0$ to 1 Do

Step14: Compute pbt[i]-(pbt[i]*(tax/100)) and append each value in $\mathrm{np}$ list

Step15: End For

Step 16: For $\mathrm{i}=0$ to $1 \mathrm{Do}$

Step17: Compute np[i]+Depreciation and append each value in ci list

Step18: End For

Step19: For $\mathrm{i}=0$ to $1+1$ Do

Step20: Compute $1 /($ math.pow $((1+d r), i+1))$ and append each value in pvf list

Ste21: End For

Step22: Insert at 0th position of ci list -initial_inv

Step19: For $\mathrm{i}=0$ to $1+1$ Do

Step20: Compute ci[i]*pvf[i] and append each value in pv list

Step22: End For

Step21: For $\mathrm{i}=0$ to $1+1$ Do

Step22: Compute sum1=sum $1+$ pv[i] 
Step23: End For

Step25: Print sum1

Step26: Stop

\section{E. Profitability Index}

Step1: Start

Step2: Import math Library

Step3: Read initial_inv (initial investment) value from the user

Step4: Read pbdt (profit before depreciation and tax), pbt (profit before tax), pvf (present value factor), pv (present value), np (net profit) and ci (cash inflow) as the empty list

Step5: Set sum1 variable as zero

Step6: Read sal_value (salvage value), 1 (expected life), dr (discount rate) and tax from the user

Step7: Compute dr=dr/100

Step8: For $\mathrm{i}=0$ to $1 \mathrm{Do}$

Step9: Read Profit Before Depreciation and Tax for each year from the user and append it in pbdt list

Step10: End For

Step11: Compute Depreciation= $($ initial_inv-sal_value $) / 1$

Step12: For $\mathrm{i}=0$ to 1 Do

Step13: Compute pbdt[i]-Depreciation and append each value in pbt list

Step14: End For

Step15: For $\mathrm{i}=0$ to $1 \mathrm{Do}$

Step16: Compute pbt[i]-(pbt[i]*(tax/100)) and append each value in $\mathrm{np}$ list

Step17: End For

Step 18: For $\mathrm{i}=0$ to 1 Do

Step19: Compute $n p[i]+$ Depreciation and append each value in ci list

Step20: End For

Step21: For $\mathrm{i}=0$ to $1+1$ Do

Step22: Compute $1 /($ math.pow $((1+d r), i+1))$ and append each value in pvf list

Step23: End For

Step24: Insert at 0th position of ci list-initial_inv

Step25: For $\mathrm{i}=0$ to $1+1$ Do

Step26 Compute ci[i]*pvf[i] and append each value in pv list

Step27: End For

Step28: For $\mathrm{i}=1$ to $1+1$ Do

Step29: Compute sum1 $=$ sum $1+$ pv[i]

Step30: End For

Step31: Compute pi=sum1/initial_inv

Step32: Print pi

Step33: Stop

\section{F. Internal Rate of Return}

Step1: Start

Step2: Import math Library

Step3: Read initial_inv (initial investment) value from the user

Step4: Read pbd (profit before depreciation), pbt (profit before tax), pvf1 (present value factor1), pvf2 (present value factor2), pv (present value), np (net profit), pv1 (present value1), pv2 (present value2) and ci (cash inflow) as the empty list

Step5: Set sum1, sum2 variable as zero
Step6: Read sal_value (salvage value), 1 (expected life), dr1 (discount rate1), dr2 (discount rate2) and tax from the user Step7: For i=0 to 1 Do

Step8: Read Profit Before Depreciation for each year from the user and append it in pbd list

Step9: End For

Step10: Compute Depreciation= $($ initial_inv-sal_value $) / 1$

Step11: For $\mathrm{i}=0$ to 1 Do

Step12: Compute pbd[i]-Depreciation and append each value in pbt list

Step13: End For

Step14: For $\mathrm{i}=0$ to 1 Do

Step15: Compute pbt[i]-(pbt[i]*(tax/100)) and append each value in $\mathrm{np}$ list

Step16: End For

Step17: For $\mathrm{i}=0$ to 1 Do

Step18: Compute np[i]+Depreciation and append each value in ci list

Step19: End For

Step20: For $\mathrm{i}=0$ to $1+1$ Do

Step21: Compute $1 /($ math.pow $((1+\mathrm{dr} 1 / 100), \mathrm{i}))$ and append each value in pvf1 list

Step22: End For

Step23: Insert at 0th position of ci list -initial_inv

Step24: For $\mathrm{i}=0$ to $1+1$ Do

Step25: Compute ci[i]*pvf1[i] and append each value in pv1 list

Step26: End For

Step27: For $i=1$ to $1+1$ Do

Step28: Compute sum1=sum1+pv1[i]

Step29: End For

Step30: For $\mathrm{i}=0$ to $1+1$ Do

Step31: Compute 1/(math.pow $((1+\mathrm{dr} 2 / 100), \mathrm{i}))$ and append each value in pvf2 list

Step32: End For

Step30: For $\mathrm{i}=0$ to $1+1$ Do

Step33: Compute ci[i]*pvf2[i] and append each value in pv2 list

Step34: End For

Step35: For $\mathrm{i}=1$ to $1+1$ Do

Step36: Compute sum2=sum2+pv2[i]

Step37: End For

Step38: Check If $\mathrm{dr} 1$ is less than $\mathrm{dr} 2$ and sum 1 is greater than $\mathrm{dr} 2$

Step39: If True, Compute irr $=\mathrm{dr} 1+((\operatorname{sum} 1 /(\operatorname{sum} 1-$ sum2) $) *(\operatorname{dr} 2-d r 1)$

Step40: Else Check If $\mathrm{dr} 2$ is less than $\operatorname{dr} 1$ and sum2 is greater than sum 1

Step41: If True, Compute irr $=\mathrm{dr} 2+((\operatorname{sum} 2 /(\operatorname{sum} 2-$ $\operatorname{sum} 1))^{*}(\operatorname{dr} 1-\mathrm{dr} 2)$

Step42: Print irr

Step43: Stop

\section{Formulas}

Payback Period=(Initial Cash Outflow)/(Annual Cash Inflows) (1)

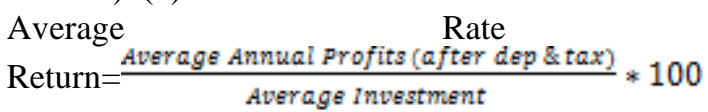

of

Net Present Value(NPV)=Present Value of Cash Inflow-

Present Value of Cash Outflow (3) 
Profitability Index $=\frac{\text { PV of cash inflows }}{\text { Inital ings }}$

Net profitability index=Profitability Index-1 (5)

IRR=Lower

Rate $+\frac{P V \text { at lower rate }}{\text { PV at lower rate-PV at higher rate }} *$ difference in rates (6)

\section{Calculations}

The bank is making an allowance for investment in a project that costs Rs. 2,00,000. The project's expected life is 5 years and has zero salvage value. The company practices straight line technique of depreciation. The company's tax rate is $40 \%$ and the interest rate is $10 \%$. The expected earnings before depreciation and before tax from the business are as follows:

\begin{tabular}{|c|c|c|c|c|c|}
\hline YEAR & 1 & 2 & 3 & 4 & 5 \\
\hline CASH & 7 & 8 & 1 & 9 & 6 \\
FLOW & 0 & 0 & 2 & 0 & 0 \\
BEFORE & 0 & 0 & 0 & 0 & 0 \\
TAX & 0 & 0 & 0 & 0 & 0 \\
& 0 & 0 & 0 & 0 & 0 \\
\hline
\end{tabular}

\subsection{Pay Back Period}

Table 6.1 Showing the Calculation of Payback Period

\begin{tabular}{|c|c|c|c|c|c|c|}
\hline YEARS & $\begin{array}{c}\text { EARNINGS BEFORE } \\
\text { DEPRICIATION \& } \\
\text { TAX }\end{array}$ & DEPRECIATION & $\begin{array}{c}\text { EARNINGS } \\
\text { BEFORE TAX }\end{array}$ & TAX & $\begin{array}{c}\text { EARNINGS } \\
\text { AFTER TAX }\end{array}$ & $\begin{array}{c}\text { NET } \\
\text { PROFIT }\end{array}$ \\
\hline 1 & 70000 & 40000 & 30000 & 12000 & 18000 & 18000 \\
\hline 2 & 80000 & 40000 & 40000 & 16000 & 24000 & 24000 \\
\hline 3 & 120000 & 40000 & 80000 & 32000 & 48000 & 48000 \\
\hline 4 & 90000 & 40000 & 50000 & 20000 & 30000 & 30000 \\
\hline 5 & 60000 & 40000 & 20000 & 8000 & 12000 & 12000 \\
\hline
\end{tabular}

Preliminary Investment $=200000$

Depreciation $=\frac{\text { Initial Investment }- \text { Salvage Value }}{\text { Number of years }}$ (6)

Since salvage value is zero, substituting the values we get, Depreciation $=\frac{200000}{5}=$ Rs. $40,000 /-$

Amount received till 2nd year=Rs. 1,22,000/-

Amount expected in 3rd year (Rs. 2,00,000 - Rs. 1,22,000)

$=$ Rs.

Table 6.2 Showing the calculation of Average Rate Of Return

\begin{tabular}{|c|c|c|c|c|c|c|c|}
\hline 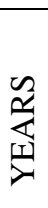 & $\begin{array}{c}\text { EARNINGS } \\
\text { BEFORE } \\
\text { DEPRECIATION } \\
\& \text { TAX }\end{array}$ & $\begin{array}{l}\text { DEPREC } \\
\text { I } \\
\text { ATION }\end{array}$ & $\begin{array}{l}\text { EARNIN } \\
\text { G S } \\
\text { BEFORE } \\
\text { TAX }\end{array}$ & TAX & $\begin{array}{l}\text { EARNI } \\
\text { N GS } \\
\text { AFTER } \\
\text { TAX }\end{array}$ & $\begin{array}{c}\text { CASH INFLOWS } \\
\text { (EARNINGS } \\
\text { AFTER } \\
\text { TAX+DEPRECIATI } \\
\text { O N) }\end{array}$ & $\begin{array}{l}\text { CUMULATIV } \\
\text { E CASH } \\
\text { INFLOWS }\end{array}$ \\
\hline 1 & 70000 & $\begin{array}{c}4000 \\
0\end{array}$ & 30000 & 12000 & 18000 & 58000 & 58000 \\
\hline 2 & 80000 & $\begin{array}{c}4000 \\
0\end{array}$ & 40000 & 16000 & 24000 & 64000 & $(58000+64000)$ \\
\hline 3 & 120000 & $\begin{array}{c}4000 \\
0\end{array}$ & 80000 & 32000 & 48000 & 88000 & $\begin{array}{c}(122000+88000 \\
)\end{array}$ \\
\hline 4 & 90000 & $\begin{array}{c}4000 \\
0\end{array}$ & 50000 & 20000 & 30000 & 70000 & $\begin{array}{c}(210000+70000 \\
)\end{array}$ \\
\hline 5 & 60000 & $\begin{array}{c}4000 \\
0\end{array}$ & 20000 & 8000 & 12000 & 52000 & $\begin{array}{c}(280000+52000 \\
)\end{array}$ \\
\hline
\end{tabular}

Preliminary Investment $=200000$

Depreciation $=($ Initial Investment-Salvage Value $) /($ Number of years)

Since salvage value is zero, substituting the values we get, Depreciation $=200000 / 5=$ Rs. 40,000/-

Net Profit $=($ Rs. $8,000+$ Rs. $24,000+$ Rs. $48,000+$ Rs.30,000

+ Rs. 12,000$)=$ Rs. $1,32,000 /-$
$78,000 /-$

Cash Inflows after tax in 3rd year= Rs. 88,000/-

$\mathrm{PBP}=2 \mathrm{Yrs}+\frac{78000}{89000}$

$=2+0.8863=2$ years 10 months and 23 days

\subsection{Average Rate of Return}

Average Annual Profit=132000/5 =Rs. 26,400

Average Investment $=($ Initial Investment + Scrap Value $) / 2$ $=200000 / 2=$ Rs. $1,00,000 /-$

Average rate of return $=($ Average Annual Profit $) /($ Average Investment $) * 100=26400 / 100000 * 100=26.4 \%$

6.3 Discounted Pay Back Period 
Table 6.3 Showing the calculation of Discounted Payback Period

\begin{tabular}{|c|c|c|c|c|c|c|c|c|c|}
\hline $\begin{array}{c}\text { YEA } \\
\text { RS }\end{array}$ & $\begin{array}{c}\text { EARNINGS } \\
\text { BEFORE } \\
\text { DEPRICIATI } \\
\text { ON \& TAX }\end{array}$ & $\begin{array}{c}\text { DEPRECIAT } \\
\text { ION }\end{array}$ & $\begin{array}{c}\text { EARNI } \\
\text { NGS } \\
\text { BEFOR } \\
\text { E TAX }\end{array}$ & TAX & $\begin{array}{c}\text { EARNI } \\
\text { NGS } \\
\text { AFTER } \\
\text { TAX }\end{array}$ & $\begin{array}{c}\text { CASH } \\
\text { FLOWS } \\
\text { (EAT+ DEP.) }\end{array}$ & $\begin{array}{c}\text { PV } \\
@ \\
10 \%\end{array}$ & $\begin{array}{c}\text { DISCOUN } \\
\text { TED CASH } \\
\text { FLOWS }\end{array}$ & $\begin{array}{c}\text { CUMULATIVE } \\
\text { DISCOUNTED } \\
\text { CASH FLOWS }\end{array}$ \\
\hline 1 & 70000 & 40000 & 30000 & 12000 & 18000 & 58000 & 0.909 & 52722 & 52722 \\
\hline 2 & 80000 & 40000 & 40000 & 16000 & 24000 & 64000 & 0.826 & 52864 & $(52722+52864)$ \\
\hline 3 & 120000 & 40000 & 80000 & 32000 & 48000 & 88000 & 0.751 & 66088 & $(105586+66088)$ \\
\hline 4 & 90000 & 40000 & 50000 & 20000 & 30000 & 70000 & 0.683 & 47810 & $(171674+47810)$ \\
\hline 5 & 60000 & 40000 & 20000 & 8000 & 12000 & 52000 & 0.621 & 32292 & $(219484+32292)$ \\
\hline
\end{tabular}

Preliminary Investment $=200000$

Depreciation=(Initial Investment-Salvage Value)/(Number of years)

Since salvage value is zero, substituting the values we get, Depreciation $=200000 / 5=$ Rs. 40,000/-

Amount received till 3rd year = Rs. 1,71,674/-

Amount expected in 4th year $\quad=\quad$ (Rs.2,00,000

Rs. $1,71,674)=$ Rs.28,326/-
Cumulative Discounted Cash Inflows after tax in 4th year $=$ Rs.47,810/-

$\mathrm{PBP}=3$ Yrs $+28326 / 48710=3+0.5924=3.5924=3$ years 7 months and

16 days

\subsection{Net Present Value Method}

Table 6.4 Showing the calculation of Net Present Value

\begin{tabular}{|c|c|c|c|c|c|c|c|c|}
\hline YEARS & $\begin{array}{c}\text { EARNINGS } \\
\text { BEFORE } \\
\text { DEPRICIAT } \\
\text { ION \& TAX }\end{array}$ & $\begin{array}{c}\text { DEPRECIATIO } \\
\mathrm{N}\end{array}$ & $\begin{array}{c}\text { EARNIN } \\
\text { GS } \\
\text { BEFORE } \\
\text { TAX }\end{array}$ & TAX & $\begin{array}{c}\text { EARNIN } \\
\text { GS } \\
\text { AFTER } \\
\text { TAX }\end{array}$ & $\begin{array}{c}\text { CASH } \\
\text { FLOWS } \\
\text { EAT+ DEP.) }\end{array}$ & $\begin{array}{c}\text { PV of } \\
\text { PASH } \\
\text { FLOW } \\
\text { S }\end{array}$ \\
\hline 1 & 70000 & 40000 & 30000 & 12000 & 18000 & 58000 & 0.909 & 52722 \\
\hline 2 & 80000 & 40000 & 40000 & 16000 & 24000 & 64000 & 0.826 & 52864 \\
\hline 3 & 120000 & 40000 & 80000 & 32000 & 48000 & 88000 & 0.751 & 66088 \\
\hline 5 & 90000 & 40000 & 50000 & 20000 & 30000 & 70000 & 0.683 & 47810 \\
\hline
\end{tabular}

Total Present Value of Cash Inflow = Rs.2,51,776.00

Present Value of Cash Outflow=Rs.2,00,000.00

NPV $=$ Present Value of Cash Influx-Present Value of Cash

6.5 Profitability Index

Outlay = Rs.2,51,776 - Rs.2,00,000 = Rs.51,776.00

Table 6.5 Showing the calculation of Profitability Index

\begin{tabular}{|c|c|c|c|c|c|c|c|c|}
\hline YEARS & $\begin{array}{c}\text { EARNINGS } \\
\text { BEFORE } \\
\text { DEPRICIATION } \\
\text { \& TAX }\end{array}$ & DEPRECIATION & $\begin{array}{c}\text { EARNINGS } \\
\text { BEFORE } \\
\text { TAX }\end{array}$ & TAX & $\begin{array}{c}\text { EARNINGS } \\
\text { AFTER } \\
\text { TAX }\end{array}$ & $\begin{array}{c}\text { CASH } \\
\text { FLOWS } \\
\text { (EAT+ } \\
\text { DEP.) }\end{array}$ & $\begin{array}{c}\text { PV } \\
@ \\
10 \%\end{array}$ & $\begin{array}{c}\text { PV } \\
\text { CASH } \\
\text { FLOWS }\end{array}$ \\
\hline 1 & 70000 & 40000 & 30000 & 12000 & 18000 & 58000 & 0.909 & 52722 \\
\hline 2 & 80000 & 40000 & 40000 & 16000 & 24000 & 64000 & 0.826 & 52864 \\
\hline 3 & 120000 & 40000 & 80000 & 32000 & 48000 & 88000 & 0.751 & 66088 \\
\hline 4 & 90000 & 40000 & 50000 & 20000 & 30000 & 70000 & 0.683 & 47810 \\
\hline 5 & 60000 & 40000 & 20000 & 8000 & 12000 & 52000 & 0.621 & 32292 \\
\hline
\end{tabular}

Net Present Value of Cash Inflows = Rs.2,51,776/-

Present Value of Cash Outflow= Rs.2,00,000/-

Profitability Index $=($ Present value of Cash Inflow $) /($ Present

6.6 Internal Rate of Return

value of Cash Outflow) $=251776 / 200000=1.2588$

Table 6.6 Showing the calculation of Internal Rate of Return

\begin{tabular}{|c|c|c|c|c|c|c|c|c|c|c|}
\hline $\begin{array}{c}\text { YEA } \\
\text { RS }\end{array}$ & $\begin{array}{c}\text { EARNING } \\
\text { S BEFORE } \\
\text { DEPRICIA } \\
\text { TION \& } \\
\text { TAX }\end{array}$ & $\begin{array}{c}\text { DEPRECIA } \\
\text { TION }\end{array}$ & $\begin{array}{c}\text { EARN } \\
\text { INGS } \\
\text { BEFO } \\
\text { RE } \\
\text { TAX }\end{array}$ & TAX & $\begin{array}{c}\text { EARNI } \\
\text { NGS } \\
\text { AFTER } \\
\text { TAX }\end{array}$ & $\begin{array}{c}\text { CASH } \\
\text { FLOWS(E } \\
\text { AT+DEP.) }\end{array}$ & $\begin{array}{c}\text { PV @ } \\
10 \%\end{array}$ & $\begin{array}{c}\text { DISCO } \\
\text { UNTED } \\
\text { CASH } \\
\text { FLOWS }\end{array}$ & $\begin{array}{c}\text { PV@ } \\
20 \%\end{array}$ & $\begin{array}{c}\text { DISCOUN } \\
\text { TED } \\
\text { CASH } \\
\text { FLOWS }\end{array}$ \\
\hline 1 & 70000 & 40000 & 30000 & 12000 & 18000 & 58000 & 0.909 & 52722 & 0.833 & 48314 \\
\hline 2 & 80000 & 40000 & 40000 & 16000 & 24000 & 64000 & 0.826 & 52864 & 0.694 & 44416 \\
\hline
\end{tabular}




\begin{tabular}{|c|c|c|c|c|c|c|c|c|c|c|}
\hline 3 & 120000 & 40000 & 80000 & 32000 & 48000 & 88000 & 0.751 & 66088 & 0.578 & 50864 \\
\hline 4 & 90000 & 40000 & 50000 & 20000 & 30000 & 70000 & 0.683 & 47810 & 0.482 & 33740 \\
\hline 5 & 60000 & 40000 & 20000 & 8000 & 12000 & 52000 & 0.621 & 32292 & 0.401 & 20852 \\
\hline
\end{tabular}

Net Discounted Cash Flows @ 10\%=Rs. 2,51,776/-

Net Discounted Cash Flows @ 20\%=Rs. 1,98,186/-

IRR=Lower Rate + (Present Value at lower rate)/(Present Value at lower rate-Present Value at higher rate)*Difference in Rates

$=10 \%+251776 /(251776-198186) *(20-10) \%$

$=56.98 \%$

\section{Results \& Discussions}

The Payback Period is 2 years 10 months and 23 days i.e. the initial investment can be recovered in the calculated time.

The Average Rate of Return is $22.40 \%$.

The Net Present Value i.e. NPV =Rs. 51,776 is satisfactory. The Internal Rate of Return i.e. IRR $=56.98 \%$ is good to an extent.

The Profitability Index is fairly good. As PI (i.e 1.2588) is greater than 1 , hence the project can be accepted.

The above calculations can be performed for different techniques and get results for the same techniques for any project where the banking organization would like to invest in and foresee whether the project they are going to invest in reaps benefits to them in future. This helps in taking the call as to choose and go with the project that is most profitable.

Generally, the calculations are done manually but the same steps can be done through automation or programmatically using python language. The above given algorithm steps when written and compiled using python language can ease the tedious task of manually updating cash flows for different successive years and computing the results for different techniques.

Most of the large organizations consider all the measures because each one provides somewhat different piece of relevant information to the decision makers and yet an impression has been created that the firms should use NPV method for decision making.

The reason why NPV is considered as superior method because it helps the organization to decide as to which project is the most profitable by ranking projects of different sizes over varying period of time.

\section{Conclusion}

All the methodologies of capital budgeting postulate that several investment offers under concern are mutually exclusive which may not essentially be accurate in certain situations. Ambiguity and threat pose major restrictions to the methods of capital budgeting. Urgency is another check in the valuation of capital investment judgements. The method of capital budgeting involves valuation of future cash inflows and outflows. The future is always undefined and the data collected may not be precise. Clearly the outcomes based upon incorrect data may not be respectable.

\section{References}

[1] Capital Budgeting Concept at: https://youtu.be/ZOaGNDmKpzo

[2] Capital Budgeting at: https://en.m.wikipedia.org/wiki/Capital_bu dgeting

[3] An Introduction to Capital Buddgeting at: https://www.investopedia.com/articles/fina ncial-theory/11/corporate- projectvaluation-methods.asp

[4] Taylor, G.A. (1964). Managerial and Engineering Economy. Van Nostrand Reinhold Cp., New York

[5] Rishi, D., \& Rao, N. (2005). Capital Budgeting Practices: A Perceptual Study, Sri Lankan Journal of Management, 10(1\&2), 93-97

[6] Mao, J.C.T. (1970). Survey of Capital Budgeting: Theory and Practice, Journal of Finance, 349-360

[7] Miller, E. (1987). The Competitive Market Assumption and Capital Budgeting Criteria, Financial Management, 16(44), 22-28

[8] Solomon, E. (1956). The Arithmetic of Capital-Budgeting Decisions, Journal of Business, 124-129

[9] Capital Budgeting Theory and Practice at: https://academized.com/samples/capitalbudgeting-theory-and-practice

[10] https://ieeexplore.ieee.org/document/5974 625

[11] Capital budgeting: a systematic review of the literature at: https://www.scielo.br/scielo.php?script=sc i_arttext\&pid=S010365132020000100402

[12] Arya, A., Fellingham, J.C. and Glover, J.C. (1998) 'Capital budgeting: some exceptions to the netpresent rule', Issues

[13] in Accounting Education, Vol 13, No. 3, pp.499-508. 
[14] Block, S. (1997) 'Capital budgeting techniques used by small business firms', Engineering Economist, Vol. 42, pp.289302

[15] Brealey, R.A., Myers, S.C. and Allen, F. (2011) Principles of Corporate Finance, 10 ed., McGraw Hill.

[16] Brounen, D., De Joung, A. and Koedijk, K. (2004) 'Corporate finance in Europe: confronting theory with practice',

[17] Financial Management, Vol. 33, pp. 71101

[18] Brennan, M. J. and Trigeorgis, L, 2000. Project Flexibility, Agency and Competition, Oxford University Press, Oxford and New York.

[19] Busby, J. S., and Pitts C. G. C., 1998. Assessing Flexibility in Capital Investment, London: The Chartered Institute of Management Accountants

[20] Butler, R., Davies, L. Pike, R., and Sharp, J., 1993. Strategic Investment DecisionMaking: Theory, Practice and Process, London/New York: Routledge

[21] Drury, C., 2003. Cost and Management Accounting, 5th edition, Thomson.

[22] Gitman, L.J. (2008) Principles of Managerial Finance, 12th ed., Pearson International.

[23] Horngren, C.T., Bhimani, A., Datar, S.M, and Foster, G., 2002. Management and Cost Accounting, 2nd edition, Hemel Hempstead: Prentice Hall.

[24] Lazaridis, I.T. (2004) 'Capital budgeting practices: a survey in the businesses of Cyprus', Journal of Small BusinessManagement, Vol. 42, No. 4, pp.427-433.

[25] Maccarone, P. (1996) 'Organizing the capital budgeting process in large firms', Management Decision, Vol. 34, No. 6, pp.43-56.

[26] Louderback, J.G., Holmen, J. S. and Dominiak, G. F., 2000. Managerial Accounting, 9th edition, South-Western College Publishing.
[27] Northcott, D., 1998. Capital Investment Decision-Making, London: International Thomson Business Press.

[28] Trigeorgis, L., 1999. Real Options and Business Strategy: Applications to Decision-Making Risk Books. Pinches, G E., 1998. Real Options: Developments and Applications, The Quarterly Review of Economics and Finance, 38, 533-536

\section{Authors Profile}

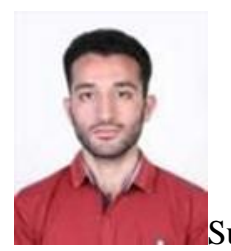

Electronics and Electrical Engineering from Acharya Institute of Technology, Bengaluru, Karnataka I am currently pursuing Masters in Business Administration from Symbiosis Institute of Computer Studies and Research, Pune.

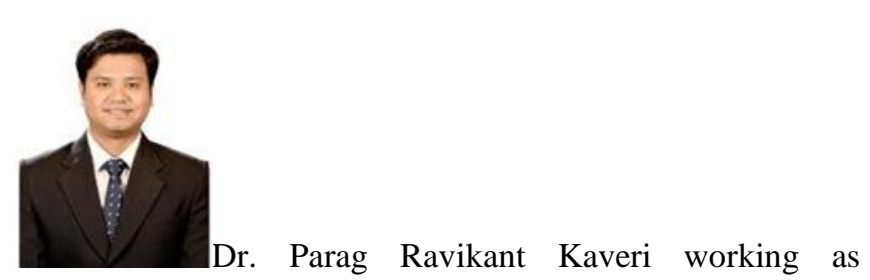
Assistant Professor and Program Head at Symbiosis Institute of Computer Studies and Research, Pune. He has 9 Years of relevant experience and published 25 plus research papers in various national and International Journal and Conferences' 